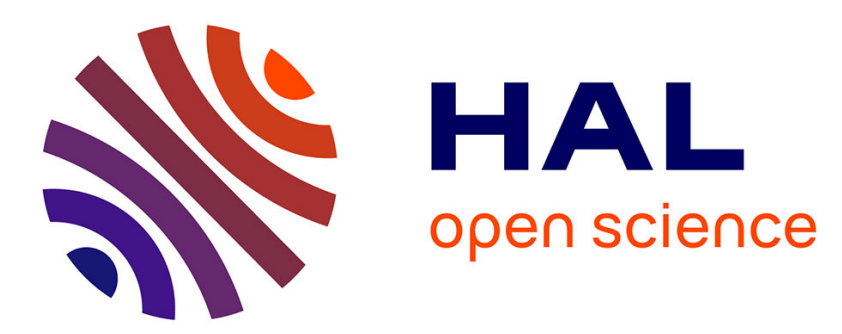

\title{
Analysis of native mitochondrial DNA in male-fertile maize mutants resistant to Helminthosporium maydis race $T$ obtained by mutagenic treatments of seeds with Texas cytoplasm
}

\author{
Elisabeth Vuillaume, Fernand Vedel, Marc Boutry
}

\section{To cite this version:}

Elisabeth Vuillaume, Fernand Vedel, Marc Boutry. Analysis of native mitochondrial DNA in malefertile maize mutants resistant to Helminthosporium maydis race $\mathrm{T}$ obtained by mutagenic treatments of seeds with Texas cytoplasm. Agronomie, 1984, 4 (3), pp.291-294. hal-00884636

\section{HAL Id: hal-00884636 https://hal.science/hal-00884636}

Submitted on 1 Jan 1984

HAL is a multi-disciplinary open access archive for the deposit and dissemination of scientific research documents, whether they are published or not. The documents may come from teaching and research institutions in France or abroad, or from public or private research centers.
L'archive ouverte pluridisciplinaire HAL, est destinée au dépôt et à la diffusion de documents scientifiques de niveau recherche, publiés ou non, émanant des établissements d'enseignement et de recherche français ou étrangers, des laboratoires publics ou privés. 


\title{
Analysis of native mitochondrial DNA in male-fertile maize mutants resistant to Helminthosporium maydis race $\mathrm{T}$ obtained by mutagenic treatments of seeds with Texas cytoplasm.
}

\author{
Elisabeth VUILLAUME, Fernand VEDEL $\left(^{*}\right) \&$ Marc BOUTRY $(* *)$.
}

I.N.R.A., Station d'Amélioration des Plantes, Laboratoire de Mutagenèse, B.V. 1540, F 21034 Dijon Cedex. (*) C.N.R.S., Laboratoire de Photosynthèse, F 91190 Gif-sur-Yvette.

(**) Université de Louvain, Laboratoire d'Enzymologie, B Louvain-La-Neuve

\begin{abstract}
Mutagenic treatment of seeds with Texas male-sterile cytoplasm, with gamma rays or ethyl methyl sulfonate, allowed us to obtain male-fertile maize resistant to Helminthosporium maydis race $\mathrm{T}$. These two traits were transmitted through the matcrnal parent. The study of the native mitochondrial DNA of 5 resistant male-fertile progenies showed that the $2.35 \mathrm{~kb}$ molecule of DNA which characterized the $\mathrm{N}, \mathrm{C}$ and $\mathrm{S}$ cytoplasms was absent from our mutants just as it was from the T cytoplasm.

Like the revertants obtaincd by in vitro culturc, the malc-fertile resistant A types showed a native mitochondrial DNA which migrated in the same way as Texas type. The electrophoretic patterns of the mitochondrial DNA digested by various restriction enzymes belonged to the Normal type; however, the material obtained by in vitro culture showed electrophoretic patterns of Texas or intermediary type according to the enzymes used. Different hypotheses are discussed to explain these phenomena.
\end{abstract}

Additional key words : Zea mays, extranuclear inheritance, plasmid-like molecule. rium maydis race $T$, obtenus par traitements mutagènes de graines à cytoplasme Texas.

Le traitement mutagène par rayons gamma ou par méthyl sulfonate d'ćthyle, de grains de maïs à cytoplasme mâle stérile Texas a permis d'obtenir des plantes mâle fertiles résistantes à Helminthosporium maydis race T. L'hérédité de ces deux caractères est cytoplasmique. L'étude du DNA mitochondrial natif de 5 descendances mâle fertiles résistantes montre qu'aucun de nos mutants, pas plus que le témoin à cytoplasme Texas, ne possède la molécule de DNA de 2,35 kb qui caractérise les cytoplasmes $\mathrm{N}, \mathrm{C}$ et $\mathrm{S}$.

Donc, comme les révertants obtenus par culture in vitro, les types A mâle-fertiles ont un DNA natif mitochondrial qui migre à la manière du type Texas.

Les diagrammes électrophorétiques du DNA mitochondrial digéré par diverses enzymes de restriction sont du type Normal au contraire du matéricl obtenu par culture in vitro qui présente des diagrammes électrophorétiques du type Texas ou de type intermédiaire, selon les enzymes testées. Différentes hypothèses sont discutćcs.

Mots clés additionnels : Zea mays, hérédité extranucléaire, molécule de type plasmidial.

\section{INTRODUCTION}

Four cytoplasmic types have been described for maize. Three of them are characterized by male sterility controlled by one or two nuclear genes specific to the respective cytoplasmic type (or group); they are the cytoplasms belonging to the Texas or « $T$ », the U.S.D.A. or « $S$ " and the Charrua or « $\mathrm{C}$ " groups. The fourth cytoplasmic type corresponds to the cytoplasmic group which does not show sterility, whatever nuclear genotype is combined with it ; it is the Normal or « $\mathrm{N}$ » cytoplasmic group.
In 1970 , the Helminthosporium maydis race $\mathrm{T}$ (HmT) outbreak in the U.S.A. forced the maize breeders to give up the use of Texas cytoplasmic male sterility and to proceed again to manual detasseling for obtaining hybrid varieties. Some research work was however undertaken in an attempt to obtain Texas male-sterile maize no longer susceptible to HmT. Two different approaches were applied: in vitro culture by GENGENBACH \& GREEN (1975) and by BRETTELL et al. $(1979,1980)$ on the one hand, and mutagenesis on the other (CASSINI et al., 1977 ; CORNU et al., 1977). None of these methods gave Texas male-sterile plants with 
heritable Hmt resistance although quite a lot of more or less male-sterile or more or less susceptible plants were obtained. Both methods also allowed one to get male-sterile plants resistant to $\mathrm{HmT}$ quite similar to the phenotype of the Normal cytoplasmic group. Both GENGENBACH and BRETTELL called these plants « variants »; we called them «A type " (CORNU et al., 1981). In both cases this Normal phenotype (male-fertile, resistant) showed cytoplasmic inheritance: both characters were exclusively inherited through the maternal parent and of course the fertility was completely independent of the presence in the nucleus of restorer genes.

The most probable hereditary factor for male sterility and HmT susceptibility in maize Texas cytoplasm has appeared to be the mitochondrial DNA (mtDNA). GENGENBACH et al. (1981) and KEMBLE et al. (1982) have studied the mtDNA of variants obtained in vitro. According to the restriction enzymes used (BamH1 and Xho1) and according to the variants, the digestion patterns belonged to Texas type or differed both from Texas and Normal types; in all cases yet studied the migration of the native mtDNA belonged to Texas type. Contrary to these variants derived from in vitro cultures, the A type mutants resulting from the treatment with gamma rays or ethyl methyl sulfonate (EMS) of seeds with Texas cytoplasm showed patterns of digestion by EcoR1 (LEAVER, pers. comm., 1980) or by BamH1 and Sal1 (BERville \& PAILlaRd, 1982) similar to those of Normal type. These results may suggest that for A type the phenotypic reversion of $\mathrm{T}$ to $\mathrm{N}$ would correspond to a true reversion of mtDNA.

Before assuming that the reversion of both traits (sterility and $\mathrm{HmT}$ susceptibility) results from a mtDNA reversion from $\mathrm{T}$ to $\mathrm{N}$ type, it is necessary to make certain that the migration of the native mtDNA also belongs to the Normal type.

\section{MATERIAL AND METHODS}

\section{A. Material}

The genotype used for this mutagenesis experiment was the F7 line on Texas cytoplasm. The plants coming from the treated seeds were crossed with the F71 line, a fertility restorer for Texas cytoplasm. According to plant fertility and vigor, various kinds of cross were then carricd out (CASSINI et al., 1977 ; CORNu et al., 1977). The A types were progeny of plants $135,473,511$ and 552 coming from seed treated with $2.5 \mathrm{~g} / 1$ of EMS and progeny of plant 1754 coming from sced treated with gamma rays ( 150 Grays).

For a better comparison of the cytoplasmic resistances obtained, offspring of the $135,473,511,552$ and 1754 plants were backcrossed with the same male nuclear genotype for several generations. However the material analysed here did not always present the same nuclear genotype. 135, 473, 511 and 1754 were backcrossed over 5 successive generations with the A632 line; 552 was backcrossed over 6 successive generations with the A619 line.

\section{B. Method}

The seeds were sterilized twice with $7 \%$ calcium hypochlorite, washed with sterile water and then grown on pozzolana under sterile conditions in the dark.

The mtDNA was prepared from $0.5 \mathrm{~g}$ etiolated shoots sampled 8 days after the start of germination. The method for preparing mtDNA was KEMBLE's method (1980) for green leaves, slightly modified. After mitochondrial lysis, the preparation was deproteinized by adding one volume of chloroform and one volume of a phenol mixture (phenol redistilled at $70 \%$, vacuum distilled m-cresol $20 \%$ and 8 hydroxy-quinoline $0.1 \%$ ). After homogenization and centrifugation (Eppendorf centrifuge), the supernatant was collected and diluted with $100 \mu \mathrm{l}$ D buffer (TRIS $10 \mathrm{mM}$, $\mathrm{NaCl} 100 \mathrm{mM}$, EDTA $1 \mathrm{mM}, \mathrm{pH} 8$ ). 2.5 volumes of cold ethanol were added and the solution was stored at $-20^{\circ} \mathrm{C}$ overnight. It was then centrifuged and dried and the pellet collected in $40 \mu 1$ of D buffer. Samples were prepared for electrophoresis by adding $5 \mu$ l of sucrose $50 \%$ in EDTA $_{4}$ $0.1 \mathrm{M}(\mathrm{pH} 8)$ and $0.02 \%$ of bromophenol blue.

Electrophoresis was carried out at room temperature on a gel with $1.2 \%$ agarose for 12 to $15 \mathrm{~h}$ and with an intensity of $30 \mathrm{~mA}$. The electrophoresis buffer contained : TRIS $50 \mathrm{mM}$, EDTA $_{4} 2 \mathrm{mM}, \mathrm{NaAc} 20 \mathrm{mM}, \mathrm{NaCl} 18 \mathrm{mM}, \mathrm{pH} 8$.

Gels were stained with ethidium bromide for $30 \mathrm{mn}$ before U.V. exposure. Photographs were made with an M.P.4 Polaroid.

\section{RESULTS}

In 1980, KEMBLE \& BEDBROOK proved that the migration of native mtDNA gave a band with a very high intensity for the main mtDNA and a variable number of DNA bands with low molecular weight and low intensity. The four cytoplasmic groups $\mathrm{N}, \mathrm{T}, \mathrm{S}$ and $\mathrm{C}$ had in common a DNA with 1.94 kilobases $(\mathrm{kb})$ which appeared on the gels under three different forms; these forms were, in increasing migration rate order, open circle (OC), linear (L) and supercoiled (CCC). All the cytoplasmic types, except T type, possessed a linear DNA with about $2.35 \mathrm{~kb}$. Each of the two cytoplasmic types $S$ and $C$ was characterized by the presence of «two unique DNA species»: for $S$, these two molecules called S1 and S2 had estimated sizes of $6.2 \mathrm{~kb}$ and $5.2 \mathrm{~kb}$; for $\mathrm{C}$, the two characteristic molecules were estimated $1.55 \mathrm{~kb}$ and $1.4 \mathrm{~kb}$. Each maize cytoplasmic type can thus be defined by the migration of native mtDNA and this technique is recommended by KEMBLE et al. (1980) to determine to which of the different maize cytoplasmic groups a particular type belongs (Table 1).

In figure 1 we can clearly see the DNA molecule of $2.35 \mathrm{~kb}$ for the controls with $\mathrm{N}$ and $\mathrm{C}$ cytoplasms (lanes a and $\mathrm{c}$ ), the absence of which is typical for T cytoplasm as well as for our five mutant families (lancs b, $\mathrm{d}, \mathrm{e}, \mathrm{f}, \mathrm{g}, \mathrm{h}$ ). For the $\mathrm{T}$ control as for the mutants, the OC form of the $1.94 \mathrm{~kb}$ DNA is easy to see whereas this is not the case for $\mathrm{N}$ and $\mathrm{C}$ controls. For all the mtDNA studied, the $\mathrm{L}$ form of this same molecule can be made out. The two typical DNA of C cytoplasm do not appear on figure 1 , lane $\mathrm{c}$.

In 1981, a first test on native mtDNA migration was carricd out for family 135 and for controls with N cytoplasm. We observed differences between $\mathrm{N}$ and the mutant similar to those we reported above, but we could not come to a definite conclusion because the $T$ control was absent. The work was done with mtDNA prepared from $50 \mathrm{~g}$ of etiolated shoots and from $10 \mathrm{~g}$ of green leaves. The nuclear genotypes were F 186, F 101, W 325 A for the N control and for family 135 (it was the fourth backcross for 135).

These two series of experiments prove that the A types are not $\mathrm{N}$ revertants, as their mtDNA does not include the $2.35 \mathrm{~kb}$ DNA molecule. It must also be stressed that this conclusion could be drawn if this $2.35 \mathrm{~kb}$ DNA did appear and if pattern variations took place after digestion by restriction enzymes. As a matter of fact, a certain heteroge- 


\section{TABLE 1}

Distribution of the plasmid-like molecules of mitochondrial DNA according to the maize cytoplasmic groups obtained by electrophoresis of native mtDNA (from KEMBLE \& BEDBROOK, 1980).

Répartition des molécules de DNA mitochondrial de type plasmidial selon les groupes cytoplasmiques du maïs, obtenus après électrophorèse du mtDNA natif (d'après KEMBLE \& BEDBROOK, 1980).

\begin{tabular}{lccccc}
\hline \multicolumn{2}{r}{ Cytoplasmic type } & $\mathrm{N}$ & $\mathrm{T}$ & $\mathrm{C}$ & $\mathrm{S}$ \\
\hline $6.2 \mathrm{~KB}$ & & & & & +++ \\
$5.2 \mathrm{~KB}$ & & & & & +++ \\
$2.35 \mathrm{~KB}$ & & ++ & & ++ & ++ \\
$1.94 \mathrm{~KB}$ & OC & + & ++ & + & + \\
& $\mathrm{L}$ & + & + & + & + \\
& $\mathrm{CCC}$ & + & + & + & + \\
$1.55 \mathrm{~KB}$ & & & & + & \\
$1.4 \mathrm{~KB}$ & & & & + &
\end{tabular}

OC : open circle, $\mathrm{L}:$ linear, CCC : supercoiled forms of the $1.94 \mathrm{~kb}$ DNA.

+++ : high intensity, $++:$ intermediate intensity, + : low intensity.

$\mathrm{OC}$ : forme circulaire ouverte, $\mathrm{L}$ : forme linéaire, $\mathrm{CCC}$ : forme superenrouléc du DNA de $1.94 \mathrm{~kb}$.

+++ : forte intensité, ++ : moyenne intensité, + : faible intensité.

neity of the restriction patterns could be observed for the $\mathrm{N}$ (LeVINGS \& PRING, 1977) and C (Pring et al., 1979) cytoplasmic groups, although the group affinities of the cytoplasm showing the differences could not be questioned.

\section{DISCUSSION}

The studied mutants as well as the variants obtained in vitro had a native mtDNA of Texas type but not the same electrophoretic patterns after digestion by the restriction enzymes.

To explain that some Texas male-sterile plants susceptible to $\mathrm{HmT}$ revert to male fertile plants resistant to $\mathrm{HmT}$ after the mutagenic treatments, two hypotheses are advanced : i) transmission of Normal mitochondria by pollen ; ii) initial association of mtDNA of Texas and Normal types. In both hypotheses Normal mtDNA would have been promoted instead of Texas mtDNA (CASSINI et al., 1977 ; CORNU et al., 1977 ; BERVILLE \& PAILLARD, 1982). The hypothesis of a point mutation is not sufficient to explain the fact that the restriction patterns obtained after digestion by EcoR1, BamH1 and Sall enzymes belong to the $\mathrm{N}$ type.

However, as the mtDNA electrophoretic patterns after digestion by the restriction enzymes are neither of Normal nor of Texas type, the phenotypic reversion of Texas to Normal type after in vitro culture could be explained as follows : mtDNA heterogeneity and « chromosomal rearrangements » (GENGENBACH et al., 1981; KEMBLE et al., 1982). This hypothesis is based on the work of various authors : QUETIER \& VEDEL (1977) proved that in plants no agreement existed between the molecular weight (Mw) estimated from the size of the mtDNA molecules and the MW estimated from restriction patterns. LEVINGS \& PRING (1979) revealed that there were several sizes of mtDNA molecules in maize and that the size frequencies varied according to the cytoplasmic group. Protoplast fusions in Nicotiana (BELliard et al., 1979) and in Brassica (PELLETIER et al., 1983) have made it possible to observe recombi-

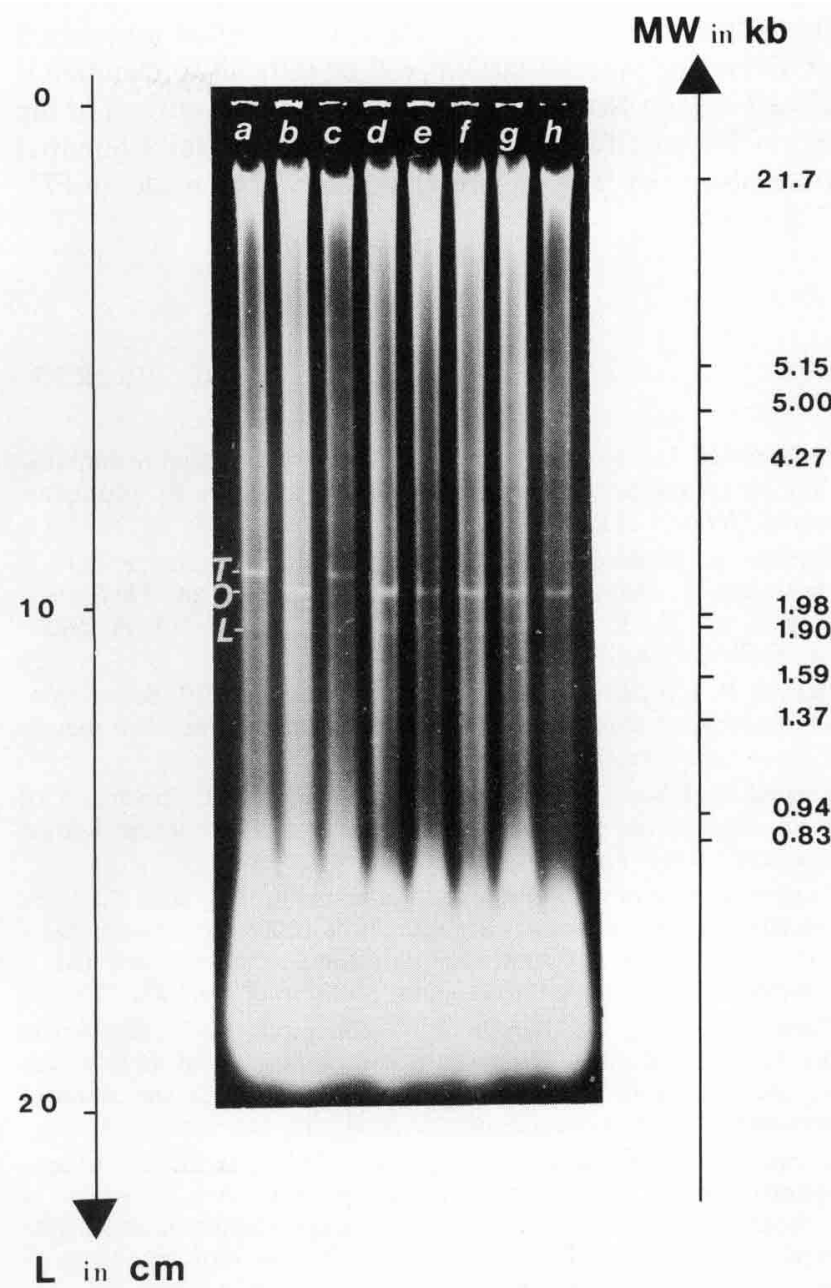

Figure 1

Agarose gel electrophoretic patterns of native mitochondrial DNA of maize. Lanes $a, b, c: A 632 \times$ Mo 17 on $N, T, C$ cytoplasms. Lanes $d, e, f, g, h$ : the five mutants families 135, 473, 511, 552 and 1754.

Molecular weight markers were digests of $\lambda$ DNA by EcoRl and HindIII (Boehringer, marker III).

$T$ : the $2.35 \mathrm{~kb} D N A$ characteristic of $N, C$, and $S$ cytoplasms. $O$ : open circle; $L$ : linear forms of the common DNA of $1.94 \mathrm{~kb}$. Diagrammes électrophorétiques sur gel d'agarose, du DNA mitochondrial natif de maïs. Puits $a, b, c: A 632 \times$ Mo 17 sur cytoplasmes $N, T, C$. Puits $d, e, f, g, h:$ les cinf familles de mutants 135,473 , 511,552 et 1754.

Les marqueurs de masse moléculaire sont des fragments de DNA du phage 入 digéré par EcoRl et HindIII (Boehringer, marker III),

$T$ : DNA de $2.35 \mathrm{~kb}$ caractéristique des cytoplasmes $N, C$ et $S$. :

$O$ : forme circulaire ouverte. $L$ : forme linéaire de la molécule de DNA commun à tous les types cytoplasmiques, de masse moléculaire $1.94 \mathrm{~kb}$.

nations between mtDNA. This work leads thus to assume that there are several types of mtDNA molecules in plant mitochondria and that intra- and/or intermolecular changes could take place to explain the cytoplasmic variants obtained on in vitro culture.

The mutants belonging to A type present plasmid-like molecules of Texas type. The two hypotheses on mutagenic treatment then seem little adapted to describe the appearance of $\mathrm{A}$ type. As in the case of in vitro culture, mechanisms of intra- and/or interchromosomal recombinations could be responsible for the A type. However KEMBLE et al. (1983) and NEWTON (1983) obtained, for the A188 and KY21 lines on Normal cytoplasm, a Texas type migration of 
the native mtDNA. The hypothesis of an initial association of Texas and Normal mtDNA will be difficult to maintain if the F7 line on Normal cytoplasm has a native mtDNA of the Normal type. To check the hypothesis of mitochondrial transmission by pollen, further studies will be made on F71, the male line of the first cross made after mutagenic treatment.

Reçu le 10 mai 1983. Accepté le 4 novembre 1983.

\section{RÉFÉRENCES BIBLIOGRAPHIQUES}

Belliard G., Vedel F., Pelletier G., 1979. Mitochondrial recombination in cytoplasmic hybrids of Nicotiana tabacum by protoplast fusion. Nature, 281, 401-403.

Berville A., Paillard M., 1982. Comment améliorer chez le maïs la résistance à Helminthosporium maydis race $\mathrm{T}$ et Phyllosticta maydis, p. 125-136. In : La sélection des plantes, I.N.R.A. publ., Les Colloques de l'I.N.R.A., $\mathbf{n}^{\circ} 11$.

Brettell R. I. S., Groddard BV. D., Ingram D. S., 1979. Selection of Tms-cytoplasm maize tissue cultures resistant to Drechslera maydis T-toxin. Maydica, 24, 203-213.

Brettell R. I. S., 'Thomas E., Ingram D. S., 1980. Reversion of Texas male sterile cytoplasm maize in culture to give fertile T-toxin resistant plants. Theor. Appl. Genet., 58, 55-58.

Cassini R., Cornu A., Berville A., Vuillaume E., Panouille A., 1977. Hérédité et caractéristiques des sources de résistance à Helminthosporium maydis race $\mathrm{T}$, obtenues par mutagenèse chez des maìs à cytoplasme mâle-stérile Texas. Ann. Amélior. Plant., 27, 753-766.

Cornu A., Cassini R., Berville A., Vuillaume E., 1977. Recherche par mutagenèse d'une résistance à Helminthosporium maydis race $\mathrm{T}$, chez des maïs à cytoplasme Texas, p. 479-488. In : Induced mutations against plant diseases, Vienna, Int. At. Energ. Agency.

Cornu A., Vuillaume E., Bodergat R., 1981. Intérêt des variants cytoplasmiques en amélioration des plantes. Application à la recherche de maïs résistants aux toxines spécifiques de la stérilité mâle cytoplasmique Texas, p. 267-275. In : Induced mutations. A tool in plant breeding, Vienna, Int. At. Energ. Agency.

Gengenbach B. G., Green C. E., 1975. Selection of T cytoplasm maize callus cultures resistant to Helminthosporium maydis race $\mathrm{T}$ pathotoxin. Crop Sci., 15, 645-649.

Gengenbach B. G., Connelly J. A., Pring D. R., Conde M. F., 1981. Mitochondrial DNA variations in maize plants regenerated during tissue culture selection. Theor. Appl. Genet., 59, 161-167.

Kemble R. J., 1980. A rapid, single leaf assay for detecting the presence of « $\mathrm{S}$ » male sterile cytoplasm in maize. Theor. Appl. Genet., 57, 97-100.

Kemble R. J., Bedbrook J. R., 1980. Low molecular weight circular and lincar DNA in mitochondria from normal and male sterile Zea mays cytoplasms. Nature, 284, 565-566.

Kemble R. J., Flavell R. B., Brettell R. I. S., 1982. Mitochondrial DNA analysis of fertile and sterile plants derived from tissue culture with the Texas male sterile cytoplasm. Theor. Appl. Genet. 62, 213-217

Kemble R. J., Gunn R. E., Flavell R. B., 1980. Classification of normal and male sterile cytoplasms in maize. 2: Electrophoretic analysis of DNA species in mitochondria. Genetics, 95, 451-458.

Kemble R. J., Gunn R. E., Flavell R. B., 1983. Mitochondrial DNA variation in races of maize indigenous to Mexico. Theor. Appl. Genet., 65, 129-144.

Levings C. S., Pring D. R., 1977. Diversity of mitochondrial genomes among normal cytoplasms of maize. J. Hered., 68, 350354.

Levings C. S. III, Shah D. M., Hu W. W. L., Pring D. R., Timothy D. H., 1979. Molecular heterogeneity among mitochondrial DNAs from different maize cytoplasms. In: Extrachromosomal DNA (ICN-UCLA Symposia), p. 63-74. New York Acad. Press.

Newton K. J., 1983. Molecular correlates of cytoplasmic types. Maize Genet. Coop. Newsl., 57, 138-139.

Pelletier G., Primard C., Vedel F., Chetrit P., Remy R., Rousselle P., Renard M., 1983. Intergeneric cytoplasmic hybridization in Cruciferae by protoplast fusion. Mol. Gen. Genet. (in press).

Pring D. R., Conde M. F., Levings C. S. III, 1979. Heterogencity within the $\mathrm{C}$ group of male sterile cytoplasms. Maize Gen. Coop. Newsl., 53, 42.

Quetier F., Vedel F., 1977. Heterogeneous populations of mitochondrial DNA molecules in higher plants. Nature, 268, 365-368. 